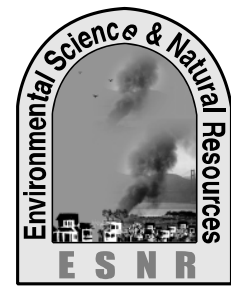

J. Environ. Sci. \& Natural Resources, 7(2): 169-175, 2014

\section{Fishing Gears and Crafts Used by the Fishers at Lohalia River in Patuakhali}

\author{
M. M. Ali ${ }^{1}$, B. C. Das ${ }^{2}$, S. M. A. Islam², M. A. Masud ${ }^{3}$ and M.Z. Rahman ${ }^{2}$ \\ ${ }^{1}$ Department of Aquaculture, \\ Patuakhali Science and Technology University, Patuakhali, Bangladesh \\ ${ }^{2}$ Department of Fisheries, Bangladesh \\ ${ }^{3}$ USAID, Bangladesh Agricultural Value Chains Project, \\ Development Alternatives Inc., Faridpur, Bangladesh
}

\begin{abstract}
Lohalia River is one of the most renowned rivers in the coastal Bangladesh and supports diverse fisheries communities. The present study was conducted to identify the types of fishing gears and crafts including their mode of operation in fishing in the Lohalia River during the period from April 2012 to March, 2013. The survey was designed to gather information on the type of gears, process of operation, cost, manpower needed for operation, seasons of operation and principal species of fish caught. The survey revealed that a wide variety of fishing gears were operated throughout the year in the study area for commercial fishing. Some of the gears were selective for a particular species, whereas others account for a number of species caught during operation giving multispecies nature of the fishing. But a number of the fishing gears was found to catch fish irrespective of their size or species and destroys the habitat of the wild species thus causing multiple harms to the biodiversity of the estuary. Training program should be conducted to the fishermen to create awareness of the long-term effects of different fishing gears and to impart knowledge of fishing laws.
\end{abstract}

Key words: Fishing gear, Fishing net, Fishing craft, Lohalia River

\title{
Introduction
}

Bangladesh is recognized as the riverine country because of having large number of rivers distributed all around it (Banglapedia, 2012). It is blessed with various inland water bodies which are very rich in diversity of fish species. It has the third major aquatic fish bio-diversity in Asia, after China and India, with about 800 species in fresh, brackish and marine waters (Hussain and Mazid, 2001). Fisheries sector already been renowned as a vital income and employment-generating sector in Bangladesh, cheap sources of healthy food for the population of the country (Akter et al., 2012; Islam et al., 2012; Azim et al., 2012; Hossain et al., 2013; Ali et al., 2014). This sector contributes $4.39 \%$ to GDP and $22.76 \%$ to agricultural GDP. Fish supplements to about $60 \%$ of our daily animal protein intake. About $10 \%$ of the population is dependent directly and indirectly on the fisheries for their living (DoF, 2013). Lohalia River is a significant riverine ecosystem situated in the coastal district, Patuakhali, Bangladesh and supports diverse fisheries communities (Ali et al., 2014). It is one of the most renowned rivers in the coastal Bangladesh and sustains country's substantial multi-species commercial fishery. Many Fishermen family is alive by catching fish in this river (Banglapedia, 2012). A large number of fishing crafts and gears are operated in the Lohalia for commercial exploitation of the fishery resources. Fishing gear is any form of equipment, implement, tool or mechanical device used to catch, collect or harvest fish. The major categories of fishing gears that are regularly used in Bangladesh can be counted as the following: fishing nets, fishing traps, hooks and lines, wounding gears and fish aggregation device (Chakraborty et al., 1995). Various types of materials are used to make these fishing gears include netting, twine, plastic structural and fasteners, clips and swivels, ropes, steel wire ropes, combination wire ropes, purse rings, polyester, polyethylene, nylon, cotton, polypropylene, mixed fibers, floats and sinkers, bamboo, wood etc. (Hameed and Boophendranath, 2000). The form and size of the gear depends on the use of gears and the environmental condition of the water body. Literatures outline the description, mode of operation and classification of fishing gears of the Lohalia River is very revealing. Such information is very much essential for developing a sound management practice for the fish exploitation in the river. Therefore, the objective in this study was to provide information about the types of fishing gears and crafts including fishing methods that are employed for the exploitation of the fishery resources in the Lohalia River of Southern Bangladesh.

\section{Materials and Methods}

The present investigation was conducted to assess the operation of used fishing gears in the Lohalia River during the period from April 2012 to March 2013. Investigations were conducted at five sampling stations on the basis of more fishermen in those areas (st1, st2, st3, st4 and st5) of Lohalia River (Figure 1). The primary data were collected from fishermen of the fishing community, fish landing centers, direct observation of fishing gears at the time of operation and from the local fishing gear market. 


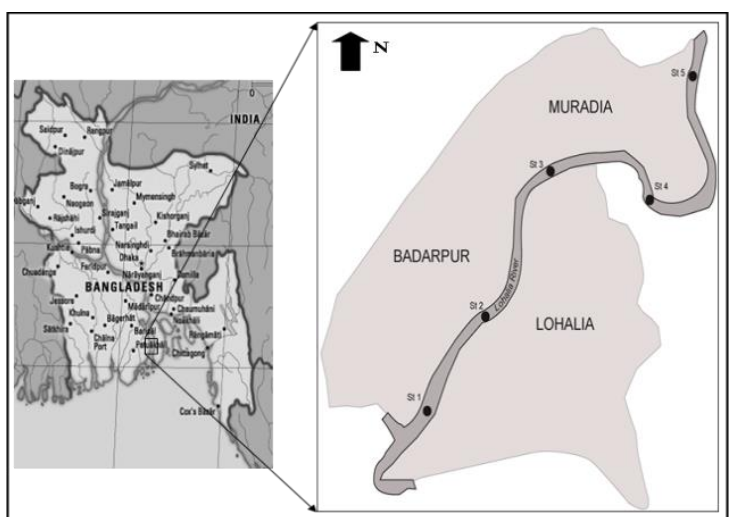

Fig. 1. Map of the study area

Data about gear size, operation mode, building materials, fish species caught, etc. were collected by interviews and personal communication from the riverine area. Interviews were conducted through face to face interview method by using semistructured open ended questions. Cross-check Interviews (CI) were conducted with key informants such as Upazila Fisheries Officer (UFO), District Fisheries Officers (DFO) and relevant GO and NGO officers and staffs. The data collected were compiled and discussed to have a clear idea about the gears operated in the Lohalia River.

\section{Results and Discussion}

The investigation showed that a wide variety of fishing gears were operated throughout the year in the Lohalia River in Patuakhali district for commercial fishing. A total of 14 types of fishing gears and crafts were observed to harvest fish in the study area (Table 1-5). Some of the gears were selective for a particular species, whereas others account for a number of species caught during operation giving multispecies nature of the fishing. The gears found in the study area were classified into four types: fish net, fish trap, hook \& line and wounding gear. Fishing net is a net used for fishing. Nets are devices made from fibers woven in a gridlike structure. Fishing nets are usually meshes formed by knotting a relatively thin thread. Later cotton was used. Modern nets are usually made of artificial polyamides like nylon, although nets of organic polyamides such as wool or silk thread were common until recently and are still used. Fishing nets were grouped into 6 categories according to the mode of operation and catching of fish viz., gill net, fixed purse net, cast net, dip net, lift net and drag/push net (Table 1).

Table 1. Different types of net used for fishing in the Lohalia River

\begin{tabular}{|c|c|c|c|c|c|}
\hline Gear Type & Local Name & $\begin{array}{l}\text { Construction Cost } \\
\text { (BDT/net) }\end{array}$ & Mesh Size (cm) & $\begin{array}{c}\text { Operational } \\
\text { Fishermen }\end{array}$ & Species Caught \\
\hline \multirow[t]{5}{*}{ Gill net } & Punti jal & 500 to 5000 & 2.2 to 3.5 & 1 to 2 & Punti, Bele, Gulsha, Bata,Koi \\
\hline & Ilish jal/Chandi jal & 300000 to 400000 & 4 to 4.5 & 10 to 15 & Hilsa, Poa \\
\hline & Bata jal & 50000 & 2.5 to 5 & 2 to 3 & Bata, Chewa, Poa \\
\hline & Poa jal & 5000 to 100000 & 3.5 & 4 to 5 & Hilsa, Poa, Bata \\
\hline & Fash jal & 15000 to 200000 & 4.5 to 15.0 & 1 to 2 & Pangas, Poa, Hilsa, Bata, Aire \\
\hline Cast net & Khepla jal & 500 to 1000 & 0.625 to 1.25 & 01 & $\begin{array}{l}\text { Bata, Chela, Taposhi, Baim, Koi, Koral, } \\
\text { Kuchia and Prawn }\end{array}$ \\
\hline $\begin{array}{l}\text { Fixed Purse } \\
\text { Net }\end{array}$ & Behundi jal & 200000 & $\begin{array}{l}5 \text { to } 6.25 \text { and } 0.5 \\
\text { to } 1.25\end{array}$ & 02 & $\begin{array}{l}\text { Bata, Kuchia, Koral, Koi, Chewa, Chiring, } \\
\text { Bashpata, Poa }\end{array}$ \\
\hline Seine net & Ber jal & 100000 to 150000 & 0.5 to 2.3 & 15 & Juvenile Pangas, Poa, Juvenile Hilsa \\
\hline Dip net & Khara jal & 10000 to 20000 & 0.5 to 2 & 01 & $\begin{array}{l}\text { Ketchki, Bele, Shoal, Taki, Punti, Koi, } \\
\text { Pangus, Poa, Tengra and Prawn }\end{array}$ \\
\hline Lift net & Dharma jal & 5000 to 50000 & 0.5 to 2 & 01 & Bele, Taki, Shoal, Punti, Koi, Gulsha, Baim \\
\hline $\begin{array}{l}\text { Drag/ Push } \\
\text { net }\end{array}$ & Thela jal & 200 to 1000 & 0.2 to 1 & 01 & Gulsha, Koi, Chewa, Prawn, Bashpata \\
\hline
\end{tabular}

\section{Gill netting}

Gill netting is a common fishing method used by commercial and artisanal fishermen of all the rivers and in some freshwater and estuary areas. Gill nets were the principal and common type of net used in the region. These are single walled nets with a mesh opening of such a size that the required fish is gilled themselves in the net. This is a passive gear, but fish can also be driven into the gill nets. The nets were used singly or in series. They are vertical walls of netting normally set out in a straight line. Floats and sinkers are attached plastic ropes are used as head ropes and foot ropes. Five types of gill nets were widely operated in the study area viz., punti jal, bata jal, ilish jal/chandi jal, poa jal and fash jal.

\section{Puntijal}

Punti jal is a rectangular shaped gill net commonly operated in the estuary made of cotton twine or monofilament. It is known as punti jal because it catches mainly punti and other small size fish. The net is 10 to $30 \mathrm{~m}$ long and 0.5 to $1.0 \mathrm{~m}$ wide having a mesh size between 2.2 and $3.5 \mathrm{~cm}$. Most punti jals have both floats and weights attached to them, though some have only floats. The net is operated in both surface layer and bottom layer of the water body. The net is usually set in the morning in shallow water but sometime it is also operated from boat both day and night. One to two persons are needed to operate the net. Cost depends on the size of the net usually varies between 500 to 5000 BDT and the life span of the net is 1-3 years. Catch per unit effort was found to be 1 to $5 \mathrm{~kg}$. It can be used 
in all over the year to catch small sized fish like Punti (Puntius spp.), Bele (Glossogobius giuris), Gulsha (Mystus cavasius), Bata (Labeo bata), Koi (Anabas testudineus), Poa (Otolithoides pama), etc. (Table 1).

\section{Ilish jal/Chandi jal}

Ilish jal is the common gill net operated in the area. The length of the net is 650 to $700 \mathrm{~m}$ and width is 10 to $12 \mathrm{~m}$ having a mesh size between 4 and 4.5 $\mathrm{cm}$. The net is constructed by Polyamide monofilaments, polypropylene or nylon rope. Both floats and sinkers are attached to the net. The net is rectangular in shape and 10 to 15 persons are needed to operate this net. The net is drifted with water current and the gill of fish is trapped in the mesh of the net. Construction cost of this net is 300000 to 400000 BDT having a life span of 3 to 4 years and has a catch per unit effort of 120 to 150 $\mathrm{kg}$. The net is operated from the boat and generally used in the whole year except the fish banning period. Mainly Hilsa (Tenualosa ilisha) and Poa (Otolithoides pama) is caught by the net (Table 1). This net is also used in Rajshahi, Khulna, Chittagong, Noakhali etc. (Ahmed, 1971).

\section{Bata Jal}

The rectangular shaped gill net which is mainly used to catch Bata fish is locally known as bata jal. The length and width of the net is 6.5 to $33 \mathrm{~m}$ and 1.25 to $2 \mathrm{~m}$ respectively, whereas the mesh size varies from 2.5 to $5 \mathrm{~cm}$ (Table 1). The net is fixed on tide near the shore by using bamboo, wood and iron but sometimes the net is operated from the boat which requires 2 to 3 persons. The construction cost of this net is 50000 BDT having a life span of 1 to 2 years. The main species trapped in the net is Bata (Labeo bata) with a catch per unit effort of 4 to 10 $\mathrm{kg}$. Seine nets are designed to be towed in an arc around fish shoals to surround them. As the seine net has a very fine mesh size, fish of both small and large size are vulnerable to such gear. Usually one end of the net is attached to a pulley or anchored on the shore and a boat is used to pull the net into a large arc back to the shore before hauling in (Kibria and Ahmed, 2005). Shatting jal/jagat ber jal and gosi jal/khoti jal are the most used type of seine net in the study area.

\section{Poajal}

Poa jal is a gill net made of polyamide monofilaments and nylon rope. The length of the net varies from 60 to $70 \mathrm{~m}$ and the width is 3.6 to $4.5 \mathrm{~m}$. The net is rectangular in shape and the mesh size of the net is $3.5 \mathrm{~cm}$. The net is operated by 4 to 5 persons from the boat in both day and night. Both floats and sinkers are attached to the net and the net is drifted with water current and the gill of fish is trapped in the mesh of the net. Construction cost of this net is 5000 to 100000 BDT having a life span of 1 to 3 years. Hilsa (Tenualosa ilisha), Poa (Otolithoides pama) and Bata (Labeo bata) are the main species caught by net (Table 1). This net is also used in the river of Dhaka, Noakhali etc. (Ahmed, 1971).

\section{Fash jal}

Fash jal is a rectangular shaped monofilament gill net with a mesh size between 4.5 and $15.0 \mathrm{~cm}$. The length of the net is 20 to 200 meter and the width is 1 meter. Floats are used at the head line, whereas ground line is provided with earthen weights. The net is fixed in the water with two bamboo poles like a large wall of net. Generally it is set on the border line or in shallow water of the estuary. The catch per unit effort of the net is $30-50 \mathrm{~kg}$ which is operated by 1 or 2 persons. Construction cost of this net is $15000-200000$ BDT having a life span of 1 to 3 years. Pangus (Pangasius pangasius), Poa (Otolithoides pama), Hilsa (Tenualosa ilisha), Bata (Labeo bata) and Ayre (Mystus aor) are the main species caught by the net (Table 1).

A cast net, also called a throw net, is a net used for fishing. It is a circular net with small weights distributed around its edge. The net is cast or thrown by hand in such a manner that it spreads out on the water and sinks. Cast net is made up of three parts: the upper section (net band), the middle section (a conical-shaped net mesh), and the lower section containing pockets fixed by iron weights. Cast net, locally known as Jhaki jal/Khapla jal, is used in the shallow region of the river to catch different types of fish.

\section{Jhaki jal/Khapla jal}

The net is conical shaped where it is 3 to $6 \mathrm{~m}$ long form anterior part to the posterior end with 6 to 12 $\mathrm{m}$ in diameter of the mouth (Table 1)). The mesh size of the net is 0.625 to $1.25 \mathrm{~cm}$. One person can operate this net as the weight of the net is 3 to $6 \mathrm{~kg}$. The net can be operated in tide, ebb-tide and in the freshwater also at both day and night. Construction cost of the net is 5000 to 10000 BDT having a catch per unit effort of 1 to $5 \mathrm{~kg}$. The main species caught by the net are Bata (Labeo bata), Chela (Salmostoma baciala), Taposhi (Polynemus paradiseus), Baim (Mastacembelus armetus), Koi (Anabas testudineus), Koral (Lates calcarifer), Kuchia (Monopterus cuchia) and Prawn. The net is found in all over the Bangladesh, known as 'khapla' in Dhaka, Mymenshing, Rajshahi, Jessor, Bogra, Pabna, Rangpur and Dinajpur, 'jhanki' in Rangpur, 'chlatki' in Chitagong, 'Dhundi and kheo' in Sylhet, 'teora' in Jessor and 'pheka' in Dinajpur (Ahmed, 1971). Framed or Dip net are triangular shaped small fishing net made of bamboo frame with which the net is fixed in a water body. This net is locally named as khara jal and mainly used at the mouth of the canal to river. Fixed Purse Net is a common type of purse seine, named such because along the bottom are a number of rings. Locally known as Behundi jal, is used in the shallow region of the river to catch different types of fish. 


\section{Behundi jal}

Behundi jal is a purse or conical in shape net and has two extensions. The length of the net is 12 to 15 $\mathrm{m}$ and width of mouth of the net is 11 to $12 \mathrm{~m}$. The mesh size at the mouth of the net is 5 to $6.25 \mathrm{~cm}$ and at the end of the pouch is 0.5 to $1.25 \mathrm{~cm}$. The net is constructed by polyamide monofilaments, polypropylene, polyvinyl chloride or nylon rope, in traditional practice the net is made up of nylon ropes and is knotted. Mouth of the net is spread and fixed on tide by bamboo, wood or iron. Fish is trapped in the centre pouch of the net and net is monitored carefully for 2 to 3 hours. Two persons are required to operate the net where the catch per unit effort is 100 to $300 \mathrm{~kg}$. The durability of the net is 2 to 3 years whereas the construction cost is 200000 BDT (Table 1). The main species trapped in the net are Bata (Labeo bata), Kuchia (Monopterus cuchia), Koral (Lates calcarifer), Koi (Anabas testudineus), Chewa (Odontambyoopus rubicundus), Chiring (Apocryptes bato), Bashpata (Brachypleura novazeelandiae), Poa (Otolithoides pama). This net is also found in Khulna and Chittagong locally known as behuti jal (Ahmed, 1971).

\section{Seine net}

Fish are captured by surrounding a certain area and towing the gear over the area with both ends to a fixed point on the shore or on a fishing vessel.

\section{Berjal}

Ber jal is a fine mesh size seine net which is commonly used in estuary. It is large in size, usually 50 to $200 \mathrm{~m}$ long and 5 to $6 \mathrm{~m}$ wide with a mesh size ranges between 0.5 and $2.3 \mathrm{~cm}$. Length, depth and mesh size vary with the depth of the area and the species to be caught(Table 1). After surrounding the part of a water body with this net, the two ends of the net are drawn together and the ground rope is hauled up from the center of the water body to catch the fish. As it has a very fine mesh size so during operation, this gear catch fish irrespective of their size or species and destroys the habitat of the wild species thus causing multiple harm to all the fish living on the estuary. So, the use of this gear is banned in the estuary in spawning season (June to October). Generally 12 to 15 people are needed to operate the net and the construction cost of this net is 200000 to 300000 BDT. Although it catches almost all types of fishes but it is mainly used to catch Juvenile Pangas (Pangasius pangasius), Poa (Otolithoides pama) and Juvenile Hilsa (Tenualosa ilisha).

A dip net is a net or a basket, which is made of wire or nylon mesh, with a long handle. They are normally used for fishing but they can also be used to scoop crabs and other crustaceans in shallow waters.

\section{Khara jal}

The net is 5 to $7 \mathrm{~m}$ long where the front side is 2.5 to $3.5 \mathrm{~m}$ wide and the mesh size of the net is 0.5 to $2 \mathrm{~cm}$ (Table 1). Two bamboos are attached at an angle of $35^{\circ}$ to make the triangular shape and a bamboo frame stage is built over the narrow canal for staying, pulling and collecting the net from the water body. The triangular portion of the net is lowered to the shallow water areas, the lower portion of the net block total passes way of fish and the fishes are trapped. The net is constructed by polyamide monofilaments, polypropylene or nylon rope but in traditional practice the net is made up of mosquito net available in the market. All small size fish are caught by the net but the main species are Ketchki (Corica soborna), Bele (Glossogobius giuris), Shoal (Channa striatus), Taki (Channa punctatus), Punti (Puntius spp.), Koi (Anabas testudineus), Pangus (Pangasius pangasius), Poa (Otolithoides pama), Tengra (Mystus vittatus) and Prawn. The net is operated by one person and generally used in the rainy season having a life span of 1 to 2 years. The construction cost of the net is 10000 to 20000 BDT having a catch per unit effort of 1 to $5 \mathrm{~kg}$.

Lift Net is a hand operated and portable net generally used in the shallow region of the river to catch small fish. This net is locally named as dharma jal.

\section{Dharma Jal}

The common shape of the net is square and it is fitted with two bamboo strips arranged in cross-bars and connected at the four corners of the net (Table 1). The arranged crossbars with the net are then attached with another lever for lifting the net from of the water. The mesh size of the net is 0.5 to 2 $\mathrm{cm}$. Sometimes the size could be made bigger and fixed at some strategic water areas e.g. Khoda Jal and Konaghar Jal. The net is generally used in the rainy season and the construction cost is 5000 to 50000 BDT. The main species caught by the net are Bele (Glossogobius giuris), Taki (Channa punctatus), Shoal (Channa striatus), Punti (Puntius spp.), Koi (Anabas testudineus), Gulsha (Mystus cavasius) and Baim (Mastacembelus armetus). The net is also used in Potuakhali, Barishal, Comilla, Dhaka, and Chittagong district of Bangladesh (Das and Banerjii, 2000). Drag nets/push nets are held apart with triangular bamboo frame and pushed manually to fish in the traditional waters of river, beels and floodplains, locally called Thela Jal.

\section{Thela jal}

Thela jal is a triangular shaped push net constructed by polyamide mono-filament nylon rope with an extended handle of two bamboo poles, one is longer than other, are fixed at an angle of $30^{\circ}$. Its' two arms are 2 to $3 \mathrm{~m}$ long and front side is 1 to $1.5 \mathrm{~m}$ long having a mesh size of 0.2 to $1.0 \mathrm{~cm}$ (Table 1). The triangular portion of the net is lowered and 
pushed forward along the bed of the shallow water areas. The net is used at all time of the year and one person can operate this net. Construction cost of this net is very low ranges from 200 to 1000 BDT. All small size fish is caught by the net but the main species are Gulsha (Mystus cavasius), Koi (Anabas testudineus), Chewa (Odontambyoopus rubicundus), Bashpata (Brachypleura novazeelandiae) and Prawn.

\section{Fishing traps}

Fishing traps are mostly bamboo and wooden made mechanical devices used in shallow water by both professional and non-professional fishermen. It is very difficult to classify the traps because same device has different names in different districts. Two types of fishing traps were identified in the study area viz., Kholsun and Bitte.

\section{Kholsun}

Kholsun is a rectangular box shaped fish trap made of split bamboo, tied with jute rope or cane and consisted of two doors from its apex for fish opening. Height, length and width of the trap are 0.75 to $1 \mathrm{~m}, 1$ to $1.25 \mathrm{~m}$ and 0.3 to $0.5 \mathrm{~m}$ respectively and the gap between two bamboo sticks is 0.5 to $1 \mathrm{~cm}$ (Table 2). The trap is set in shallow part of the estuary with the help of bamboo pole or tree branches during early morning or evening from January to July. Small fish like Baim (Mastacembelus armetus), Koi (Anabas testudineus), Punti (Puntius spp.), Tengra (Mystus vittatus), Katchki (Corica soborna), Mola (Amblypharyngodon mola), Chanda (Chanda nama), Khalisha (Colisa fasciatus) and small prawn are trapped in the trap.

\section{Bitte}

Bitte is a basket shaped fishing trap, made of split bamboo with two or three entrances and an opening on the trap for collecting fish. Height, length, width and gap between two bamboo sticks of the trap are 0.25 to $0.5 \mathrm{~m}, 0.25$ to $1 \mathrm{~m}, 0.1$ to $0.5 \mathrm{~m}$ and $0.5-1.0$ $\mathrm{cm}$ respectively (Table 2$)$. The trap is sunken $(0.1$ to $0.75 \mathrm{~m}$ below from water surface) in shallow water, where small current is present during early morning and evening checked up every one or two hour interval. Usually small fishes are caught by the trap including Baim (Mastacembelus armetus), Koi (Anabas testudineus), Punti (Puntius spp.), Tengra (Mystus vittatus), small prawn etc.

Table 2: Different Types of Trap used for Fishing in Lohalia River

\begin{tabular}{|c|c|c|c|c|c|}
\hline \multirow{2}{*}{$\begin{array}{c}\text { Name of } \\
\text { Traps }\end{array}$} & \multicolumn{3}{|c|}{ Size of trap (Approximately) } & \multirow{2}{*}{ Made with } & \multirow[t]{2}{*}{ Species Caught } \\
\hline & Height & Length & Width/Dia. & & \\
\hline Kholsun & 0.75 to $1 \mathrm{~m}$ & 1 to $1.25 \mathrm{~m}$ & 0.3 to $0.5 \mathrm{~m}$ & Bamboo stick & $\begin{array}{l}\text { Punti, Koi, Baim, Punti, Tengra, Katchki, } \\
\text { Mola, Chanda, Khalisha }\end{array}$ \\
\hline Bitte & 0.25 to $0.5 \mathrm{~m}$ & 0.25 to $1 \mathrm{~m}$ & 0.1 to $0.5 \mathrm{~m}$ & Bamboo split & Baim, Koi, Punti, Tengra, small prawn etc. \\
\hline
\end{tabular}

\section{Hooks and lines}

Hooks are manufactured in a wide range of size, and the gap between the point and the shank appears to be the dimension, which determines the size range of fish caught by a particular hook. The most familiar type of manufactured steel hook is "J'" shaped, which is mostly used for hook and line fishing. Three types of hooks and lines were found in the study area.

\section{Sip barshi}

Sip or Barshi is a very simple barbed hook tied with one end of a line and the other end with a bamboo stick (Table 3). Above the hook there is a float used to drift the hook into desired sub surface of water level which also indicates that if the fish is baited or not. Earth warm and small prawn is used as bait. Main fish species caught by this type of gear are Kalibaus (Labeo calbasu), Koi (Anabas testudineus), Shing (Heteropneustes fossilis), Punti (Puntius spp.), Rita (Rita rita), Tengra (Mystus vittatus) and some carp species.

\section{Wheel barshi}

Wheel barshi is moderately barbed hook tied with one end of a line and the other end with a bamboo stick and controlling site (Table 3). Above the hook there is a float used to drift the hook into desired sub surface of water level which also indicates that if the fish is baited or not. Earth warm and small prawn is used as bait. Main fish species caught by this type of gear are Kalibaus (Labeo calbasu), Koi (Anabas testudineus), Shing (Heteropneustes fossilis), Punti (Puntius spp.), Tengra (Mystus vittatus) and some carp species.

\section{Daun}

Daun is a long line measuring from 46 to $450 \mathrm{~m}$, which is set into shallow water with bamboo pools 4 to $6 \mathrm{~cm}$ above water. A small line of 0.45 to $1 \mathrm{~m}$ with barbed hooks is lowered into water with bait. The baits include earthworm, cockroach, punti and guchi fish and toad. One daun may contain even more than 500 hooks. In the secondary river, the two opposite and the long line is set on the two opposite banks across the river sinkers. But in the Estuary the line is attached with large sinker for lowering and the two other ends are attached to two floats. Fish caught by this long line are Baim (Mastacembelus armetus), Taposhi (Polynemus paradiseus), Shoal (Channa striatus), Taki (Channa punctatus), Gazar (Channa marulius) etc.

\section{Wounding gears}

Spears are the fishing devices which are used to catch fish by throwing or wounding fishes. Two types of spears are mainly used in the Lohalia River. 


\section{Konch}

Konch is similar to juti but more than 10 pieces of bamboo splits are firmly fixed in a bunch. The pointed ends of the bamboo splits are covered with sharp and pointed iron caps to increase the efficiency. The fishermen wait with great patience from a boat or from any craft or just standing on the bank of water body and when find the fish, throw the gear with a great force at the fish so as to pin down, when strikes the fish. Fish caught by this gear are Rui (Labeo rohita), Catla (Catla catla), Shoal (Channa striatus), Gozar (Channa marulius) etc. (Table 4).
Teta

Teta is a wounding gear made of a long bamboo handle about 2 to 4 long and several iron hooks with iron rod at the base (Table 4). The length of iron rod is about 60 to $65 \mathrm{~cm}$ with hooks at the apex. The iron rod with hooks is tightly tied with the bamboo handle by coconut thread or iron wire. The fisherman throws the gear to target species like Boal (Wallago attu), Shoal (Channa striatus), Taki (Channa punctatus), Bele (Glossogobius giuris) and others fish species.

In addition to the use of gears for fishing, other devices viz. hand catch, fishing by katha fishing (spots where bushes/branches of plants are accumulated to gather fishes) are also practiced in all the study area.

Table 3.Different types of hooks and line used for fishing in the Lohalia River

\begin{tabular}{|l|l|l|l|l|l|}
\hline $\begin{array}{c}\text { Types of } \\
\text { Gear }\end{array}$ & Name of gear & No. of hooks & $\begin{array}{c}\text { Person } \\
\text { needed }\end{array}$ & \multicolumn{1}{c|}{$\begin{array}{c}\text { Boat } \\
\text { needed }\end{array}$} & \multicolumn{1}{c|}{ Species Caught } \\
\hline $\begin{array}{l}\text { Hook and } \\
\text { line }\end{array}$ & Sip barshi & 1 & 1 & $\begin{array}{l}\text { No Boat } \\
\text { Needed }\end{array}$ & $\begin{array}{l}\text { Kalibaus, Koi, Shing, Punti, Tengra } \\
\text { and some carp species. }\end{array}$ \\
\cline { 2 - 6 } & Wheel barshi & $1-4$ & 1 & $\begin{array}{l}\text { No Boat } \\
\text { Needed }\end{array}$ & $\begin{array}{l}\text { Kalibaus, Koi, Shing, Punti, Tengra } \\
\text { and some carp species. }\end{array}$ \\
\cline { 2 - 6 } & Daun & $200-500$ & $1-2$ & $\begin{array}{l}\text { Boat } \\
\text { Needed }\end{array}$ & $\begin{array}{l}\text { Baim, Taposhi, Shoal, Taki, Gazar } \\
\text { etc. }\end{array}$ \\
\hline
\end{tabular}

Table 4.Different types of wounding gears used for fishing in the Lohalia River

\begin{tabular}{|c|l|l|l|l|}
\hline \multicolumn{1}{|c|}{ Types of gear } & \multicolumn{1}{|c|}{$\begin{array}{c}\text { Name of } \\
\text { gear }\end{array}$} & $\begin{array}{c}\text { Length of handle } \\
(\mathbf{m})\end{array}$ & $\begin{array}{c}\text { Parson and boat } \\
\text { needed }\end{array}$ & \multicolumn{1}{|c|}{ Species Caught } \\
\hline Wounding Gears & Konch & $2-3$ & $1 \&$ no & $\begin{array}{l}\text { Kalibaus, Koi, Shing, Punti, } \\
\text { Tengra and some carp species. }\end{array}$ \\
\cline { 2 - 5 } & Teta & $2-3$ & $1 \&$ no & Boal, Shoal, Taki, Bele \\
\hline
\end{tabular}

\section{Fishing crafts}

Different types of fishing crafts like kosa boat, vedi boat, dingi boat, bhoat boat, and rafts were dominantly used for fish capture (Table 5).
Commonly used crafts were of various types, sizes and designs. Ahmed (1954) and Hussain (1977) described the utilization of traditional crafts.

Table 5. Different types of crafts used for fishing in the Lohalia River

\begin{tabular}{|l|l|l|l|l|}
\hline \multirow{2}{*}{ Craft Name } & \multicolumn{2}{|l|}{ Measurement of the craft } & \multirow{2}{*}{ Gear used in craft } & \multirow{2}{*}{ Man power needed } \\
\cline { 2 - 3 } & Length $(\mathbf{m})$ & Wide $(\mathbf{m})$ & & $1-4$ \\
\hline Kosa boat & $3-5$ & $1-2$ & Khepla jal, ber jal etc. & $1-6$ \\
\hline Dinghy boat & $4-10$ & $1-2$ & Ber jal, fash jal, veshal jal & $2-4$ \\
\hline Bhoat boat & $4-7$ & $1.5-2$ & Khepla jal, current jal, barshi, fash jal & 2 \\
\hline
\end{tabular}

Different types of crafts are also essential to assure a good and effective fishing. The fresh water fishing craft and gears are of traditional types, using from long times without any modifications. Same observation or results are found in the study area. Most of the fishing gears have to break off operations after a certain period of activity, for rest and repair (Khanna, 1989).

\section{Conclusions}

Lohalia River is very rich with fishery resources but the use of fishing gears that catch fish irrespective of their size or species will destroy the habitat of the wild species thus causing multiple damages to all the fish living in the river. For that, the use of selective fishing gears which have the capability to catch fish of distinguishing size and species will help to protect the target species hence reduce the loss of fish biodiversity. As the operation of all types of gear cannot be banned immediately to allow the stocked fingerlings to grow out, it is important to identify the gear that can be operated without exploiting undersized fingerlings stocked under the government plan and the gear that should be regulated. At the same time, an awareness or training program should be conducted under the supervision of the government as well as nongovernment organizations to the fishermen to create awareness of the long-term effects of different fishing gears and to impart knowledge of fishing 
laws. After all, the main fundamental objective of responsible fishing is to maximize economic returns to the fishermen without affecting the long-term sustainability of the fishery resources and with minimum impact on the ecosystem.

\section{References}

Ahmed, N. 1954. Fishing craft of East Pakistan. Directorate of Fisheries. East Pakistan Govt. Tech. 20.

Ahmed, N. 1971. Government of East Pakistan Directories of Fisheries: Fishing Gear of East Pakistan. East Pakistan Fishery Department, East Pakistan.

Akter, H.; Islam, M.R. and Hossain, M.B. 2012. Fecundity and Gonadosomatic Index (GSI) of Corsula, Rhinomugil corsula Hamilton, 1822 (Family: Mugilidae) from the Lower Meghna River Estuary, Bangladesh. Global Veterinaria, 9 (2):129-132.

Ali, M.M.; Hossain, M.B.; Minar, M.H.; Rahman, S. and Islam, M.S. 2014. Socio-Economic Aspects of the Fishermen of Lohalia River, Bangladesh. Middle-East Journal of Scientific Research, 19 (2): 191-195.

Azim, M.A.; Islam, M.R.; Hossain, M.B and Minar, M.H. 2012. Seasonal Variations in the Proximate Composition of Gangetic Sillago,Sillaginopsis panijus (Perciformes: Sillaginidae), Middle-East J. Sci. Res., 11 (5): 559-562

Banglapedia, National Encyclopedia of Bangladesh, Asiatic Society of Bangladesh, 1st edition February, 2012. Dhaka, Bangladesh.

Banglapedia. 2006. Fishing Gear, National Encyclopedia of Bangladesh. Asiatic Society of Bangladesh, Dhaka.

Chakraborty, S.C.; Hossain, M.A. and Hoq, M.E. 1995. Traditional inland fishing methods in Bangladesh. J. Asiat. Soc. Bangladesh Sci., 21 (1): 19-27.
Das, B. and Banerjii, A. 2000. Matshya sangrah projukti (Fish Harvesting Technology), Vol. 11. Bangla Academy, Dhaka 1000, Bangladesh.

DoF. 2013. National Fish Week 2013 Compendium, Department of Fisheries, Ministry of Fisheries and Livestock, Bangladesh.144p

Hameed, M.S. and Boophendranath, M.R. 2000. Modern Fishing Gear Tchnology, Das Publishing House, Dellhi, 3 pp.

Hossain M.B.; Amin S.M.N.; Shamsuddin, M. and Minar, M.H. 2013. Use of Aqua-Chemicals in the Hatcheries and Fish Farms of Greater Noakhali, Bangladesh. Asian J. Anim.Vet. Advances, 8(2): 401-408.

Hussain, M. 1977. Design of two standard steel body fishing crafts for all seasons operation in the Bay of Bengal, National marine Fisheries seminar. Edited by A. L. Bhuiyan and A. K. Chowdhury

Hussain, M.G. and Mazid, M.A. .2001. Genetic improvement and conservation of carp species in Bangladesh. Bangladesh Fisheries Research Institute and International Center for Living Aquatic Resources Management.

Islam M.R.; Sultana N.; Hossain, M.B. and Mondal, S. 2012. Estimation of Fecundity and Gonadosomatic Index (GSI) of Gangetic Whiting, Sillaginopsis panijus (Hamilton, 1822) from the Meghna River Estuary, Bangladesh. World Appl. Sci. J., 17 (10): 12531260 .

Khanna, S.S. 1989. An introduction to fishes. Published by central book dept. Allahabad. 2nd ed. $486 \mathrm{p}$.

Kibria, M.G. and Ahmed, K.K.U. 2005. Diversity of Selective and Non-Selective Fishing Gear and their Impact on Inland Fisheries in Bangladesh. World Fish Center Newsletter. 28(1,2): 43-48. 